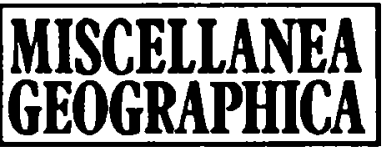

WARSZAWA 1996 Vol. 7

Jadwiga Winidowa

\title{
THE METHOD OF "DISTANCES AND PERCENTAGE SHARES" OF WALENTY WINID. APPLICATION TO TOWNS OF BANGLADESH
}

It is not only for commemorating the 50th anniversary of the death of Polish geographer Walenty Winid, ${ }^{1}$ but also in order to remind of the originality of his approach to the settlement studies, it is worthwhile to recall and illustrate one of the methods of determination of the degree of development of the urban network, applied by him.

This method, called the "method of distances and percentage shares", presented in 1930 in Belgrade at the Third Congress of Slavonian Geographers and Ethnographers ${ }^{2}$, resulted from the studies conducted over the period of several years in 1920 s in the United States.

The interest in the problems of towns and urbanization was the result of a critical attitude of $\mathrm{W}$. Winid to the research methods applied in urban geography of that time. The degree of urbanization was usually expressed through percentage share of urban population in total population numbers or per unit surface. According to W. Winid such an approach is a simplification of the problem and does not allow adequate grasping of the settlement phenomena. Urban population is concentrated in settlements which appear in geographical space in the form of "islands surrounded by the non-urban landscape".

W. Winid travelled in the region of Great Lakes (the states of Illinois, Indiana, Ohio, Minnesota, Wisconsin, as well as the adjacent agricultural state of Iowa) and noticed that the frequency of appearance of towns was relatively low, while the percentage share of urban population was high. $\mathrm{He}$ compared this situation with the one in Poland and stated that in spite of the fact that the share of urban population in Poland was much lower, the

\footnotetext{
${ }^{1}$ see, in the same issue: D. Jędrzejczyk - "Studies on human settlement and relakted concepts of Walenty Winid (1894-1945)".

${ }^{2}$ Zbornik Radova na III Kongresu Slovenskich Geografa i Etnografa u Jugoslaviji 1930, Beograd 1932.
} 
frequency of appearance of towns (spatial density of towns) was much higher.

That is why, according to $\mathrm{W}$. Winid, the measurement of the urbanization level should be made not only with the percentage share of urban population in its total number, but also with the degree of development of the urban network. W. Winid proposed the following elements for the description of the degree of development of the urban network within an area perhaps an administrative unit of some definite level:

a. percentage share of the urban population in total population number

b. urban population per 1 sq. $\mathrm{km}$ of the unit considered

c. total population

$d$. urban population $\quad c ., d$. and e.: per one urban settlement (in '000)

e. rural population

$f$. theoretical trade area in sq. $\mathrm{km}$

g. theoretical distance between urban centres, in $\mathrm{km}$

$h$. number of urban settlements per $100 \mathrm{sq} . \mathrm{km}$

A complementary indicator was constituted by population density per 100 sq. km.

The author of the concept here described, when making his stance with respect to the measures proposed by him more precise, states that the indicator denoted with $a$. makes it possible to order the analysed administrative units according to their urbanization level; while the one denoted with $b$. - has a theoretical nature, because urban population is characterized by concentration in definite centres, called "islands" by W. Winid. When analysing the differences in the level of development of the urban network one should, in the opinion of $\mathrm{W}$. Winid, account for the number of towns in the units considered. Due, however, to their different surfaces, a definite reference unit must be adopted, like $100 \mathrm{sq}$. $\mathrm{km}$ or $1,000 \mathrm{sq}$. $\mathrm{km}$ (indicator denoted $h$.). The same indicator can be also analysed conversely, that is - by expressing the level of urban network development through the magnitude of surface per one urban settlement, i.e. by dividing the surface of the unit considered by the number of towns there located (indicator $f$.).

The latter constitutes, according to the author of the concept, the theoretical average trade area of every urban settlement, the so called "service area". Thereby the area of the reference unit is divided up into equal surfaces in whose middle part an urban centre is located, providing service in the domain of trade (both supply and purchase) to local population.

One of the most important questions in the study of the degree of development of the urban network is consideration of distance between urban centres. According to W. Winid the theoretical distance between the urban centres (indicator $g$.) is the square root of the magnitude of the service area. The remaining indicators, i.e. $c ., d$. and $e$. express total population number, as well as urban and rural population per one urban centre. According to the author referred to these three indicators $(c ., d$. and $e$.) 
may give rise to some doubts, and especially bring out the question whether the information obtained from calculations may indicate the lower or the higher degree of development of the urban network. W. Winid takes no stance with this respect, but, due to the results of the studies conducted, brings attention to the different ordering of the administrative units in each of the cases considered (the data for the indicators $c$., $d$. and e.). On the other hand, orderings of these administrative units conform to the data for the indicators $f$., $g$. and $h$. are identical.

The analysis of the orderings of the administrative units on the basis of the eight indicators proposed by $\mathrm{W}$. Winid has shown that two different sequences are obtained:

- the first one, expressed by the percentage share of urban population in relation to total population numbers;

- the second one, namely the ranking of urban settlements in relation to surface.

The remaining sequences, in view of lack of common features with the ones above, and of their inadequacy, may, in the opinion of W. Winid, be rejected.

Thus, identical ordering of the reference units can be observed in the case when we compare the following variables: the number of settlements per unit surface (indicator $h$.) and the urban population per unit surface (indicator $b$.), as well as, though only partly so, rural population per one urban settlement. Hence, in three cases, when the basis for ordering is entirely or partly different, this ordering is identical. A similar agreement, though, is not observed in the case of percentage share of urban population in total population number. Therefore, in the opinion of $W$. Winid, the level of development of the urban network is in an essential way determined by the relation between the number of urban settlements in a given administrative unit and the area of this unit.

Finally, after the analysis has been carried out of the indicators mentioned before, the degree of development of the urban network can be expressed with:

- the number of urban settlements per surface unit,

- theoretical magnitude of the surface of a given unit per one settlement,

- theoretical distance between the urban settlements.

Among these three W. Winid distinguishes especially, as providing, in his opinion, the best expression of the degree of development of the urban network, the theoretical distance between the urban centres. This indicator reflects the spatial frequency of appearance of towns in the definite region, not reflected by the percentage share of urban population in this area. That is why, according to the author considered, the differences in the level of development of the urban network can be more precisely expressed with the analysis of distances than solely through the urban population percentage 
share analysis. W. Winid states, though, that definition of the level of development of the urban network with the help of the urban population percentage share indicator is necessary for the needs of statistics, economics and sociology, and even in geographical studies, but only when population problems are treated in abstraction from the overall context of the phenomena, of the geographical environment.

To base the studies of the level of urbanization solely on the indicator expressing the percentage share of urban population in total population numbers means, in the opinion of $\mathrm{W}$. Winid, to simplify the question approached, since, according to him, appearance of towns as existing entities, "facts, rooted in the landscape", is thereby neglected. Geography, in the eyes of W. Winid, is the science which inquires into the "facts" and their spatial distribution, and this statement applies also to towns. Thus, in his opinion, the methods of "distances", applied in the study of the development level of the urban network, fulfils the requirement set on the geographical method.

W. Winid maintains that the level of development of the urban network should be defined not only through the analysis of distances, but also by the nurivers of urban and rural population per one urban settlement. The study carried out by the same author at the end of $1920 \mathrm{~s}$ indicated that, for instance, in the state of Ohio the average distance between towns was 26.7 $\mathrm{km}$, and the numbers of urban and rural population per one urban settlement were, respectively, 24,800 and 14,100 . In the state of North Dakota the same numbers were as follows: $123.2 \mathrm{~km}, 7,340$ and 46,600.

Such an approach to the problem of the level of development of the urban network puts an emphasis on the spatial frequency of appearance of towns, gives an idea as to the towns' dimension, the density of their appearance, allows to determine the numbers of urban and rural population (as well as total population) per one town on the average, and to calculate population density. ${ }^{3}$ It also gives the basis for many geographical, economic and sociological studies.

The method of analysis of the level of development of the urban network proposed by W. Winid was highly appraised by the American Statistical Association, and deemed ingenious.

Among Polish geographers of 1930s, Professor Stanisław Pawłowski, working in particular in the domain of geography of towns, stated in his opinion on the subject here considered: "the theoretical trade area was called theoretical because it cannot practically be determined. The range of the trade-related influence of a town depends upon its location and magnitude. The influence of Chicago reaches both oceans. I do not know the method for deter-

\footnotetext{
${ }^{3}$ Population density can be calculated by dividing the total number of population per one urban centre $(d+e)$ by the squared theoretical distance between the urban centres $\left(g^{2}\right)$.
} 
mining the true trade area of a town. The negative side of this method is that large towns are treated in the same manner as the small ones. The identical shortcoming characterizes, though, the statistical method, which is not capable of eliminating the metropolitan towns." According to S. Pawłowski, W. Winid, being aware of the shortcoming of his method, proposed the determination of the level of urbanization through both the percentage share of the urban population and the "distancing" of the urban settlements.

The present author has recently applied the here described method of analysis of the development of the urban network to the towns of Bangladesh. Calculations were performed with respect to the administrative units of the first order, the so called divisions, on the basis of the National Censuses' data from 1981 and partly $1991 .{ }^{4}$ In 1981 urban population of Bangladesh amounted to $15.2 \%$ (13.2 million) of the total, with the town count at 451 . In 1991 the share exceeded 25\%, and the number of urban centres attained 543. Bangladesh is still characterized by the low level of urbanization. Yet, one observes a strong persisting tendency to the increase of the urban population share. In the period 1981-1991 the yearly average rate of increase of this population was $6.2 \%$.

The development of the urban network in Bagladesh according to divisions is illustrated with the data of Table 1 . The information obtained from calculations makes it possible to note that in 1981 in the divisions of Dhaka and Khulna, featuring the highest shares of urban population, the theoretical distance between urban centres was the smallest. On the other hand in Rajshahi, where the percentage share of urban population was the lowest, the theoretical distance between towns was close to that in the divisions of Dhaka and Khulna. Certain differences started to be visible only in $1991 .^{5}$

The overview of the data from Table 1 makes it possible to observe that the urban centres in Dhaka division are distanced on the average by $13.4 \mathrm{~km}$, with the urban population number per one urban centre being 49.5 thousand and the rural population number being 198 thousand, while the theoretical trade area of a town amounted here on the average to $180.9 \mathrm{sq} . \mathrm{km}$.

Then, in Chittagong division towns are distanced by $20.4 \mathrm{~km}$ on the average, with 28.9 thousand of the urban and 164 thousand of the rural population per one urban centre, and the theoretical trade area of an urban centre exceeding 417 sq. $\mathrm{km}$. In Barisal the respective values are $19.8 \mathrm{~km}$, 26.8 thousand, 214.2 thousand and $492.4 \mathrm{sq} . \mathrm{km}$, which indicates a lower level of development of the urban network in this administrative unit in comparison with the previously considered ones.

\footnotetext{
4 The National Census of population was carried out in March 1991 and its results have not been published until now. A selection of data on urban problems of the last decade is provided by the Statistical Pocketbook of Bangladesh - 1993.

${ }^{5}$ The percentage shares of urban population are not defined for the same period because of lack of data.
} 
Table 1

The development level of the urban network in Bangladesh according to divisions* in 1981 and 1991

\begin{tabular}{|c|c|c|c|c|c|c|}
\hline & Rok & Barisal & Chittagong & Dhaka & Khulna & Rajshahi \\
\hline $\begin{array}{l}\text { Population } \\
\text { density per } \\
1 \text { sq. km }\end{array}$ & $\begin{array}{l}1981 \\
1991 \\
\end{array}$ & $\begin{array}{l}489.4 \\
561.2 \\
\end{array}$ & \begin{tabular}{|l}
487.3 \\
588.5 \\
\end{tabular} & $\begin{array}{r}843.2 \\
1049.7 \\
\end{array}$ & \begin{tabular}{|}
477.7 \\
569.6 \\
\end{tabular} & $\begin{array}{r}612.2 \\
759.4 \\
\end{array}$ \\
\hline $\begin{array}{l}\text { a. \% share } \\
\text { of urban } \\
\text { population }\end{array}$ & 1981 & 11.1 & 15.0 & 16.6 & 16.3 & 10.1 \\
\hline $\begin{array}{l}\text { b. urban } \\
\text { population } \\
\text { per } 1 \mathrm{sq} . \mathrm{km}\end{array}$ & $\begin{array}{r}1981 \\
1991^{2} \\
\end{array}$ & $\begin{array}{r}54.45 \\
28.95 \\
\end{array}$ & $\begin{array}{r}73.09 \\
52.12 \\
\end{array}$ & $\begin{array}{r}168.57 \\
175.58 \\
\end{array}$ & $\begin{array}{r}78.05 \\
65.50 \\
\end{array}$ & $\begin{array}{r}61.74 \\
57.22 \\
\end{array}$ \\
\hline $\begin{array}{l}\text { c. population } \\
\text { total }^{2}\end{array}$ & $\begin{array}{l}1981 \\
1991 \\
\end{array}$ & $\begin{array}{l}241,028 \\
219,500 \\
\end{array}$ & $\begin{array}{l}193,119 \\
245,838 \\
\end{array}$ & $\begin{array}{r}247,565 \\
189,918 \\
\end{array}$ & $\begin{array}{l}141,893 \\
129,469 \\
\end{array}$ & $\begin{array}{r}183,756 \\
204,756 \\
\end{array}$ \\
\hline $\begin{array}{l}\text { d. urban } \\
\text { population }\end{array}$ & 1981 & 26,816 & 28,965 & 49,490 & 23,180 & 18,530 \\
\hline $\begin{array}{l}\text { e. rural } \\
\text { population }\end{array}$ & 1981 & 214,212 & 164,154 & 198,075 & 118,713 & 165,226 \\
\hline $\begin{array}{l}\text { f. theoretical } \\
\text { trade area } \\
\text { in sq. } \mathrm{km}\end{array}$ & $\begin{array}{l}1981 \\
1991 \\
\end{array}$ & $\begin{array}{l}492.4 \\
391.0 \\
\end{array}$ & \begin{tabular}{|l|}
396.2 \\
417.7 \\
\end{tabular} & $\begin{array}{r}293.5 \\
180.9 \\
\end{array}$ & \begin{tabular}{|l|}
296.9 \\
227.2 \\
\end{tabular} & $\begin{array}{l}300.1 \\
269.6 \\
\end{array}$ \\
\hline $\begin{array}{l}\text { g. theoretical } \\
\text { distance } \\
\text { between urban } \\
\text { settlement } \\
\text { in km }\end{array}$ & 1991 & 19.8 & 20.4 & 17.1 & 15.0 & 16.4 \\
\hline $\begin{array}{l}\text { h. number of } \\
\text { urban } \\
\text { settlements } \\
\text { per } \\
100 \text { sq. } \mathrm{km}\end{array}$ & 1991 & 0.20 & 0.25 & 0.34 & 0.34 & 0.33 \\
\hline
\end{tabular}

* Division - first order administrative unit

${ }^{1}$ per urban settlement

2 The data encompass the population living uniquely in 107 municipal towns in 1991

Sources: Own calculations on the basis of:

1. Population of Bangladesh. Country Monograph Series, No. 8, ESCAP, United Nations, New York.

2. Statistical Pocketbook of Bangladesh 1993. Bangladesh Bureau of Statistics, Dhaka, Dec. 1993.

The Tables 2 and 3 present the analysed reference units, ordered according to the levels of development of the urban network, taking as the basis the eight indicators proposed by W. Winid. Table 2 was elaborated on the basis of the uniform statistical data for the year 1981. Table 3 - due to par- 
Table 2

Divisions of Bangladesh according to the degree of development of the urban network in $1981^{*}$

\begin{tabular}{|c|c|c|c|c|c|}
\hline $\begin{array}{l}\text { a. \% share of urban } \\
\text { population }\end{array}$ & Dhaka & Khulna & Chittagong & Barisal & Rajshahi \\
\hline $\begin{array}{l}\text { b. urban population } \\
\text { per } 1 \mathrm{sq} . \mathrm{km}\end{array}$ & Dhaka & Khulna & Chittagong & Rajshahi & Barisal \\
\hline c. population total ${ }^{1}$ & Dhaka & Barisal & Chittagong & Rajshahi & Khulna \\
\hline d. urban population ${ }^{1}$ & Dhaka & Chittagong & Barisal & Khulna & Rajshahi \\
\hline e. rural population ${ }^{1}$ & Barisal & Chittagong & Dhaka & Rajshahi & Khulna \\
\hline $\begin{array}{l}\text { f. theoretical trade area } \\
\text { in sq. } \mathrm{km}\end{array}$ & Barisal & Chittagong & Rajshahi & Khulna & Dhaka \\
\hline $\begin{array}{l}\text { g. theoretical distance } \\
\text { between urban settlement } \\
\text { in } \mathrm{km}\end{array}$ & Barisal & Chittagong & Rajshahi & Khulna & Dhaka \\
\hline $\begin{array}{l}\text { h. number of urban } \\
\text { settlements per } 100 \mathrm{sq} . \mathrm{km}\end{array}$ & Dhaka & Khulna & Chittagong & Rajshahi & Barisal \\
\hline
\end{tabular}

Administrative units were ordered from the highest to the lowest values of the indicators, according to the data contained in Table 1 .

1 per urban settlement

Source: Own calculations.

Table 3

Divisions of Bangladesh according to the degree of development of the urban network in 1981 and $1991^{*}$

\begin{tabular}{|l|l|l|l|l|l|l|}
\hline $\begin{array}{l}\text { a. \% share of urban } \\
\text { population }\end{array}$ & $1981^{2}$ & Dhaka & Khulna & Chittagong & Barisal & Rajshahi \\
\hline $\begin{array}{l}\text { b. urban population } \\
\text { per 1 sq. km }\end{array}$ & $1991^{3}$ & Dhaka & Khulna & Rajshahi & Chittagong & Barisal \\
\hline c. population total & 1991 & Chittagong & Barisal & Rajshahi & Dhaka & Khulna \\
\hline d. urban population & $1981^{2}$ & Dhaka & Chittagong & Barisal & Khulna & Rajshahi \\
\hline e. rural population & $1981^{2}$ & Barisal & Chittagong & Dhaka & Raishahi & Khulna \\
\hline $\begin{array}{l}\text { f. theoretical trade } \\
\text { area in sq. km }\end{array}$ & 1991 & Chittagong & Barisal & Rajshahi & Khulna & Dhaka \\
\hline $\begin{array}{l}\text { g. theoretical } \\
\text { distance between } \\
\text { urban settlement } \\
\text { in km }\end{array}$ & 1991 & Chittagong & Barisal & Rajshahi & Khulna & Dhaka \\
\hline $\begin{array}{l}\text { h. number of urban } \\
\text { settlements } \\
\text { per 100 sq. km }\end{array}$ & 1991 & Dhaka & Khulna & Rajshahi & Barisal & Chittagong \\
\hline
\end{tabular}

Administrative units were ordered from the highest to the lowest values of the indicators, according to the data contained in Table 1 .

${ }^{1}$ per urban settlement

${ }^{2}$ Lack of data for the year 1991

${ }^{3}$ Data concern population living uniquely in 107 municipal towns in 1991

Source: Own calculations. 
tial lack of data $^{6}$ for 1991 provides merely a general guideline on the scale of the problem. The comparison of the sequences of the analysed administrative units, ordered according to the indicators adopted shows a similarity with the results obtained by $\mathrm{W}$. Winid. Thus, ordering of the reference units on the basis of the indicators $h$ (number of settlements per $100 \mathrm{sq} . \mathrm{km}$ ) and $b$ (urban population number per $1 \mathrm{sq} . \mathrm{km}$ ) is identical. Similarly, in the case of indicators $f$ (theoretical trade area in sq.km) and $\mathrm{g}$ (theoretical distance between settlements) the obtained sequences are alike. This likeness, however, was not observed for the latter indicators and the indicator $h$ (number of settlements per 100 sq. $\mathrm{km}$ ), though $\mathrm{W}$. Winid saw such a (theoretical) similarity. The sequence obtained as the result of the analysis of the indicator a (percentage share of urban population in total population number) gives in the majority of cases a different image than for the other indicators.

The analysis carried out by the present author confirms the proposition of $\mathrm{W}$. Winid, namely that the level of development of the urban network is most adequately expressed by the indicators referring to the per area quantities, complemented by the indicator of the percentage share of urban population. In spite of the fact that the method of assessment of the level of development of the urban network proposed by $\mathrm{W}$. Winid encountered a certain criticism, attention should be paid to the new perspective on the problems of towns, suggested by him, the perspective unknown yet at the turn of 1930s.

The theory of W. Christaller ${ }^{7}$, with its fundamental assumption of appearance of a system of hierarchically ordered central places in the geographical space, was published in 1933.

We know today that there exist towns which do not only have their influence regions, but also attract and absorb other towns into the confines of their influence areas. A town is namely a settlement unit which does not live in isolation. A small town is attracted into the influence area of a bigger neighbouring urban centre, which, in turn, gravitates towards a superior unit. Thus, a structure develops which links towns into a unified network, encompassing the whole country with its links. The role of a town in the urban network of a country depends upon the town's magnitude, upon the degree of urbanization of the country, the functional character of the town and many other factors. Due to his research carried out 70 years ago W.Winid indicated the fact that the purely statistical perspective on the urban problems is insufficient, especially for the geographers, who ought to display the ability of interpretation of the complex spatial reality.

\footnotetext{
6 The respective data refer to both 1981 and 1991.

7 W. Christaller, 1933, Die Zentralen Orte in Sueddeutschland. Eine oekonomischegeographische Untersuchung ueber die Gesetzmaessigkeit der Verbreitung und Entwicklung der Siedlungen mit staedtischen Funktionen (The Central Places is Southern Germany. An Economic-Geographical Study on the Regularities of the Growth and Development of the Settlements with Urban Functions). Jena.
} 